\title{
POTENSI PUPUK HIJAU ORGANIK(Daun Trembesi, Daun Paitan, Daun Lantoro) SEBAGAI UNSUR KESTABILAN KESUBURAN TANAH
}

\author{
Misbach Munir ${ }^{1)}$ \\ Dosen Program Studi Teknik Industri UYP \\ M. Aniar Hari Swasono ${ }^{2)}$ \\ Dosen Program Studi Agrobisnis UYP
}

\begin{abstract}
Abstrak
Upaya konservasi sumber daya alam hayati seringkali menjadi prioritas kesekian dalam pembangunan di negara Indonesia. Perhatian dan dukungan elemen masyarakat baik pemerintah, swasta maupun individu sangat minim sehingga pada masa ini terjadi degradasi status keanekaragaman hayati dari yang semula dikenal sebagai daerah dengan keanekaragaman tinggi (mega diversity country) menjadi negara dengan tingkat keterancaman paling tinggi (hot spot country). Salah satu indikasi paling sederhana adalah semakin berkurangnya jenis-jenis tanaman lokal seperti pohon Trembesi (Samanea Saman), daun paitan (Tithonia diversifolia)dan daun lantoro (Leucaena leucocephala) daun-daunan tersebut merupakan komoditas penting karena merupakan salah satu sumber pupuk organik yang paling baik bagi penghumusan tanah. Beberapa jenis tumbuan lain seperti pohon lantoro dan paitan juga dilaporkan mengandung banyak zat hijau serta unsur N,P,K yang mampu memulihkan kondisi tanah dengan subur tanpa mengurangi PH tanah yang selama ini telah tecampur dengan bahan kimia.

Permasalahan yang sering terjadi adalah para petani masih sering memakai pupuk yang berbahan kimia Akibatnya racun bahan kimia yang terkandung dalam tanah semakin meningkat, beberapa jenis tanaman yang mampu mengembalikan kondisi tanah mengalami proses pelangkaan dan bahkan terancam kepunahan, sehingga tujuan penelitian ini adalah 1) Apa saja kandungan yang terdapat pada jenis daun-daunan sebagai bahan baku utama pupuk hijau organik.2). Bagaimana cara proses produksi pupuk hijau organik.3) Bagaimana hasil studi kelayakan pupuk hijau organik serta hasil perbandingan unsur haranya

Berdasarkan Studi Uji lab kandungan unsur hara N,P,K banyak terdapat pada daun - daunan terutama Daun trembesi dengan kandungan unsur $(N)=6.52$, unsur $(P)=0.47$ dan unsure $(K)=2,25$. Untuk daun paitan kandungan unsur $(N)=4,65$, unsur $(P)=0,25$ dan unsur $(K)=64,52$. Sedangkan untuk daun lantoro unsur $(N)=3,37$, unsur $(P)=0.31$ dan unsur $(K)=0,37$. Dari data uji lab tersebut dalam setiap unsur hara serta kandungan zat hijau yang terdapat pada daun trembesi menunjukkan bahwa nilai kandungan unsur $(N)$ pada daun trembesi berada diatas nilai yang distandarkan, sedangkan untuk unsure $(K)$ yang berada diatas nilai standar terdapat pada daun paitan dan unsure $(P)$ yang berada diatas nilai standart terdapat pada daun lantoro. Dengan demikian kandungan unsure ketiga bahan tersebut dapat kita gabungkan untuk dijadikan sebagai alat ukur pada variabel proses produksi pupuk hijau organic yang akan diuji.Dari hasil Studi karakter, fenologi, habitat, etnobotani dan kearifan tradisional, menyatakan bahwa ada pengaruh terhadap kondisi tanah yang kritis yang semula tidak begitu subur dengan tingkat pencemaran zat kimia tinggi, telah berangsur pulih akibat penghumusan yang di akibatkan dari pupuk hijau organik tersebut.
\end{abstract}

Kata Kunci :Trembesi,Paitan,Lantoro, Unsur Hara, Pupuk organi

\section{PENDAHULUAN}

Upaya konservasi sumber daya alam hayati seringkali menjadi prioritas kesekian dalam pembangunan di negara Indonesia. Perhatian dan dukungan elemen masyarakat baik pemerintah, swasta maupun individu sangat minim sehingga pada masa ini terjadi degradasi status keanekaragaman hayati dari yang semula dikenal sebagai daerah dengan keanekaragaman tinggi (mega diversity country) menjadi negara dengan tingkat 
keterancaman paling tinggi (hot spot country). Salah satu indikasi paling sederhana adalah semakin berkurangnya jenis-jenis tanaman lokal seperti pohon Trembesi (Samanea Saman), daun paitan (Tithonia diversifolia)dan daun lantoro (Leucaena leucocephala) yang dulu banyak dijumpai di pedesaan serta daerah pegunungan dan kebun-kebun milik masyarakat kini jarang sekali diketemukan dan kalaupun ada jumlahnya sangat terbatas dan hanya terlokalisir di suatu daerah tertentu. Padahal, pohon Trembesi atau lebih dikenal pohon juar ini merupakan komoditas penting karena merupakan salah satu sumber pupuk organik yang paling baik bagi penghumusan tanah. Beberapa jenis tumbuan lain seperti pohon lantoro dan paitan juga dilaporkan mengandung banyak zat hijau serta unsur N,P,K yang mampu memulihkan kondisi tanah dengan subur tanpa mengurangi $\mathrm{PH}$ tanah yang selama ini telah tecampur dengan bahan kimia.

Permasalahan yang sering terjadi adalah para petani masih sering memakai pupuk yang berbahan kimia karena jenis-jenis tersebut memiliki keunggulan-keunggulan lebih cepat tumbuh hijau dibandingkan jenis pupuk organik lain. Di samping itu keberadaan keanekaragaman pupuk ini cenderung kurang diperhatikan, oleh karena potensi keanekaragaman sumberdaya tanaman Trembesi sebagai bahan utama pupuk hijau organik ini belum dimanfaatkan secara optimal, terutama jenis pupuk yang belum populer, semisal pupuk organik lain Akibatnya racun bahan kimia yang terkandung dalam tanah semakin meningkat, beberapa jenis tanaman yang mampu mengembalikan kondisi tanah mengalami proses pelangkaan dan bahkan terancam kepunahan. Sesuai dengan kesepakatan internasional, kita ketahui bahwa setiap spesies memiliki hak untuk hidup. Suatu spesies diciptakan dengan membawa nilai etika, ekologis, estetika, kultural, ekonomi dan intrinsik secara spesiflk, sehingga spesies yang punah tidak dapat sepenuhnya digantikan fungsinya oleh spesies yang lain (WRI, IUCN, UNEP, 1995). Pupuk Hijau Organik tidak hanya berpotensi untuk meningkatkan kesejahteraan manusla sebagai sumber penganekaragaman tanaman tetapi juga berpotensi sebagal komponen perbaikan lingkungan sesuai dengan kondisi setempat.

\section{Rumusan Masalah}

1.Apa saja kandungan yang terdapat pada jenis daun-daunan sebagai bahan baku utama pupuk hijau organik.

2.Bagaimana cara proses produksi pupuk hijau organik

3.Bagaimana hasil studi kelayakan pupuk hijau organik serta hasil perbandingan unsur haranya.

\section{Tujuan Penelitian}

1.Mengetahui kandungan yang terdapat pada jenis daun-daunan sebagai bahan baku utama pupuk organik

2.Mengetahui bagaimana cara proses produksi pupuk hijau oganik

3.Mengetahui kelayakan proses produksi pupuk hijau organik dari perbandingan hasil unsur haranya

\section{Tinjauan Pustaka}

\section{Proses produksi Pupuk Hijau Organik}

Proses produksi merupakan proses perubahan barang melalui tranformasi perubahan, mulai dari input bahan baku, mesin, tenaga kerja dan lain sebagainya sampai proses akhir hingga menjadi barang yang lebih berkualitas / bermutu. aktifitas kerja yang berkaitan langsung dengan suatu 
barang untuk mengubah dedaunan, limbah dan beberapa bahan yang lain menjadi produk pupuk hijau organik dalam bentuk butiran padat yang sangat bermanfaat untuk peningkatan $\mathrm{PH}$ serta tingkat kesuburan pada tanah yang memiliki nilai tambah bagi perusahaan juga bagi para petani,adapun fungsi unsur hara dalam proses pertumbuhan dan perkembangan tanaman.

ketika kita memberi pupuk pada tanaman secara tidak langsung kita memberikan unsur hara pada tanaman tersebut. Jadi secara umum unsur hara berfungsi sebagai bahan makanan bagi tanaman. Setiap unsur hara berfungsi berbeda-beda dalam proses pertumbuhan dan perkembangan suatu tanaman. Secara singkat fungsi dari 16 unsur hara tersebut adalah:

1. Karbon (C)

Sebagai pembangun utama bahan organik

2. Oksigen

Sebagai pembangun bahan organik.

3. Hidrogen

Merupakan elemen pokok pembangunan bahan organik.

4. Nitrogen $(\mathrm{N})$

Diperlukan untuk pembentukan atau pertumbuhan bagian vegetatif tanaman, seperti daun, batang dan akar. Berperan penting dalam hal pembentukan hijau daun yang berguna sekali dalam proses fotosintesis. Membentuk protein, lemak dan berbagai persenyawaan organik. Meningkatkan mutu tanaman penghasil daun-daunan. Meningkatkan perkembangbiakan mikro-organisme di dalam tanah.

5. Fosfor

Merangsang pertumbuhan akar, khususnya akar benih/tanaman muda. Mempercepat serta memperkuat pertumbuhan tanaman muda menjadi tanaman dewasa dan menaikkan prosentase bunga menjadi buah/biji. Membantu asimilasi dan pernafasan sekaligus mempercepat pembungaan dan pemasakan buah, biji atau gabah. Sebagai bahan mentah untuk pembentukan sejumlah protein tertentu.

6. Kalium (K)

Membantu pembentukan protein dan karbohidrat. Berperan memperkuat tubuh tanaman, mengeraskan jerami dan bagian kayu tanaman, agar daun, bunga dan buah tidak mudah gugur. Meningkatkan daya tahan tanaman terhadap kekeringan dan penyakit. Meningkatkan mutu dari biji/buah.

7. Kalsium (Ca)

Merangsang pembentukan bulu-bulu akar Berperan dalam pembuatan protein atau bagian yang aktif dari tanaman Memperkeras batang tanaman dan sekaligus merangsang pembentukan biji Menetralisir asamasam organik yang dihasilkan pada saat metabolisme Kalsium yang terdapat dalam batang dan daun dapat menetralisirkan senyawa atau suasana keasaman tanah

8. Magnesium (Mg)

Magnesium merupakan bagian tanaman dari klorofil Merupakan salah satu bagian enzim yang disebut Organic pyrophosphatse dan Carboxy peptisida Berperan dalam pembentukan buah

9. Belerang (Sulfur $=\mathrm{S}$ )

Berperan dalam pembentukan bintilbintil akar Merupakan unsur yang penting dalam beberapa jenis protein dalam bentuk cystein, methionin serta thiamine Membantu pertumbuhan anakan produktif Merupakan bagian penting pada tanaman-tanaman penghasil minyak, sayuran seperti cabai, kubis dan lainlain Membantu pembentukan butir hijau daun.

10. Besi (Fe) 
Zat besi penting bagi pembentukan hijau daun (klorofil) Berperan penting dalam pembentukan karbohidrat, lemak dan protein Zat besi terdapat dalam enzim Catalase, Peroksidase, Prinodic hidroginase dan Cytohrom oxidase

11. Mangan (Mn)

Diperlukan oleh tanaman untuk pembentukan protein dan vitamin terutama vitamin C Berperan penting dalam mempertahankan kondisi hijau daun pada daun yang tua Berperan sebagai enzim feroksidase dan sebagai aktifator macam-macam enzim Berperan sebagai komponen penting untuk lancarnya proses asimilasi

12. Tembaga $(\mathrm{Cu})$

Diperlukan dalam pembentukan enzim seperti: Ascorbic acid oxydase, Lacosa, Butirid Coenzim A. dehidrosenam Berperan penting dalam pembentukan hijau daun (khlorofil)

13. Seng $($ Zincum $=\mathrm{Zn})$

Dalam jumlah yang sangat sedikit dapat berperan dalam mendorong perkembangan pertumbuhan Diperkirakan persenyawaan Zn berfungsi dalam pembentukan hormon tumbuh (auxin) dan penting bagi keseimbangan fisiologis Berperan dalam pertumbuhan vegetatif dan pertumbuhan biji/buah

14. Molibdenum (Mo)

Berperan dalam mengikat (fiksasi) $\mathrm{N}$ oleh mikroba pada leguminosa Sebagai katalisator dalam mereduksi $\mathrm{N}$ Berguna bagi tanaman jeruk dan sayuran

15. Boron (Bo)

Bertugas sebagai transportasi karbohidrat dalam tubuh tanaman Meningkatkan mutu tanaman sayuran dan buah-buahan Berperan dalam pembentukan/pembiakan sel terutama dalam titik tumbuh pucuk, juga dalam pembentukan tepung sari, bunga dan akar Boron berhubungan erat dengan metabolisme Kalium (K) dan Kalsium (Ca) Unsur hara Bo dapat memperbanyak cabang-cabang nodule untuk memberikan banyak bakteri dan mencegah bakteri parasit 16. Khlor (Cl)

Memperbaiki dan meninggikan hasil kering dari tanaman seperti: tembakau, kapas, kentang dan tanaman sayuran

\section{Bahan Baku Proses Produksi Pupuk Hijau Organik}

Bahan baku pupuk hijau organik merupakan dekomposisi bahan-bahan organik atau proses perombakan senyawa yang komplek menjadi senyawa yang sederhana dengan bantuan mikroorganisme. Bahan dasar pembuatan pupuk hijau organik ini antara lain yaitu:

a) Dari jenis daun - daunan:

- Daun Trembesi (Samanea saman)

Samanea saman yang sering disebut dengan Trembesi (Rain tree) merupakan tanaman pelindung yang mempunyai banyak manfaat. Trembesi dapat bertahan 2-4 bulan atau lebih lama di daerah yang mempunyai curah hujan $40 \mathrm{~mm} /$ tahun (dry season) atau bahkan dapat hidup lebih lama tergantung usia, ukuran pohon, temperatur dan tanah. Trembesi juga dapat hidup di daerah dengan temperatur $20-300^{\circ} \mathrm{C}$, maksimum temperatur $25-380^{\circ} \mathrm{C}$, minimum 18 $200^{\circ} \mathrm{C}$, temperatur minimum yang dapat ditoleransi $80^{\circ} \mathrm{C}$. Tanaman peneduh hujan ini akan tumbuh 15-25 m (50-80 $\mathrm{ft}$ ) di tempat terbuka dengan diameter kanopi (payung) lebih besar dari tingginya.

Trembesi berbentuk melebar seperti payung (canopy), pohon yang masuk dalam sub famili Mimosaceae dan famili Fabaceae ini biasa ditanam 
sebagai tumbuhan pembawa keteduhan. Uniknya, daun pohon saman bisa mengerut di saat-saat tertentu, yaitu 1,5 jam sebelum matahari terbenam dan akan kembali mekar saat esok paginya setelah matahari terbit. Jika hujan datang, daun-daunnya kembali menguncup. Bentuk dahannya kecil kecil seperti dahan putri malu. Daun ini tumbuh melebar seperti pohon beringin, tetapi tidak simetris alias tidak seimbang. Bijinya mirip dengan biji kedelai, hanya warna cokelatnya lebih gelap. Bunganya menyerupai bulu-bulu halus yang ujungnya berwarna kuning, sementara pada dasar bunga berwarna merah. Buahnya memanjang, berwarna hitam kala masak dan biasa gugur ketika sehabis matang dalam keadaan terpecah. Setiap panjang tangkainya berukuran 7-10 sentimeter.

Tumbuhan ini berasal dari Amerika tropik namun sekarang tersebar di seluruh daerah tropika. Di Indonesia, orang menjuluki tanaman ini dengan sebutan Ki Hujan atau trembesi, sementara dalam bahasa Inggris dinamai rain tree (pohon hujan), monkeypod atau saman. Asal muasalnya dari Hawaii, tetapi banyak tersebar di kepulauan Samoa, daratan Mikronesia, Guam, Fiji, Papua Nugini dan Indonesia.

Manfaat Trembesi:

- Trembesi merupakan jenis pohon yang memiliki kemampuan menyerap karbondioksida dari udara yang sangat besar. Pohon ini mampu menyerap 28.488,39 kg CO $2 /$ pohon setiap tahunnya. Berdasarkan penelitian Hartwell (1967-1971) di Venezuela, akar trembesi dapat digunakan sebagai obat tambahan saat mandi air hangat untuk mencegah kanker. Ekstrak daun trembesi dapat menambah kesuburan tanah dengan tingkat keseburan tertinggi dibandingkan daun -daunan lain dengan unsure ( $\mathrm{N}$ 6,52), (P. 0,47), (K 2,25) (Duke and Wain, 1981)

- Daun paitan (Tithonia diversifolia) Daun paitan (Tithonia diversifolia), Berdasarkan hasil penelitian Kami di Universitas Yudharta pasuruan, jenis tanaman tersebut terbukti mengandung metabolit sekunder pada bagian akar maupun daun.. daun paitan banyak terdapat di sekitar kita. Budaya para petani menggunakan pestisida kimia sistesis berdampak negatif dan positif. Dampak positif berupa meningkatnya produksi pertanian dan dampak negatif berupa resistensi hama pada pestisida bila digunakan berlebihan, dan juga masalah lingkungan yang ditimbulkan. Kekayaan alam Indonesia berpotensi sebagai sumber pestisida nabati sebagai alternatif pembasmi alami hama khususnya ulat grayak. Aplikasi insektisida nabati selama ini dinilai belum efektif. paitan yang dikombinasikan dengan daun trembesi, diharapkan menghasilkan kombinasi insektisida yang lebih efektif sehingga dapat diaplikasikan di masyarakat luas. Tujuan dari penelitian ini adalah untuk mengetahui potensi daun paitan ( $T$. diversifolia), dalam meningkatkan efektifitas insektisida nabati untuk membasmi ulat grayak (Spodoptera litura). Penelitian ini merupakan jenis penelitian eksperimen dengan melihat mortalitas ulat grayak (Spodoptera litura). sedangkan bahan yang digunakan berupa ekstrak daun paitan, Langkah kerja yang digunakan yaitu sterilisasi alat, pembutan pakan, persiapan isolat S/NPV, pembuatan ekstrak daun paitan, pelaksanaan uji, dan pengamatan mortalitas ulat grayak selama 14 hari. Hasil Kombinasi air 
perasan daun paitan, berpengaruh terhadap mortalitas ulat grayak. Kombinasi air perasan daun paitan terbukti efektif dalam meningkatkan mortalitas larva S. Litura. Efektifitas bahan dapat disebabkan karena adanya kandungan dalam bahan tersebut yang bekerja sama secara sinergis sehingga menghasilkan daya bunuh larva yang tinggi dalam waktu yang singkat, yaitu kurang dari 3 hari (72 jam).

- Lantoro (Leucaena leucocephala) Lantoro (Leucaena leucocephala) termasuk jenis pohon legum yang bersifat perennial dengan perakaran yang dalam. Dapat tumbuh dengan baik pada daerah kering Pertumbuhannya relatif cepat, tahan terhadap pemangkasan yang berulang ulang.

Tanda dan sifat lantoro : Berdaun dan berbiji banyak, berbiji polong, bunga bulat, tumbuh tinggi, cepat dipanen dan menyuburkan tanah. Kandungan yang terdapat pada daun lantoro:

Tabel 1. Kandungan Unsur Hara Daun Lantoron

\begin{tabular}{|c|c|c|c|}
\hline Tolok ulur & Kadar & $\begin{array}{c}\text { Potonsi Sumbangan Hara } \\
\text { per ha per tahun }\end{array}$ & Kesetaraannya dengan Pupuk \\
\hline Rendemen & $40 \%$ & . & - \\
\hline C & $46.80 \%$ & $134-162 \mathrm{~kg}$ & $20-279 \mathrm{~kg}$ Bahan Organik \\
\hline N & $3.37 \%$ & $10-12 \mathrm{~kg}$ & $2-26 \mathrm{~kg}$ Urea \\
\hline P & 0.318 & $2 \mathrm{~kg}$ & $6 \mathrm{~kg} S \mathrm{P} 36$ \\
\hline K & $0.37 \%$ & tkg & $2 \mathrm{~kg} K \mathrm{KCl}$ \\
\hline $\mathrm{Ca}$ & $4.30 \%$ & $17-21 \mathrm{~kg}$ & $57-70 \mathrm{~kg}$ Dolomit \\
\hline Mg & $0.35 \%$ & $2 \mathrm{~kg}$ & $7 \mathrm{~kg}$ Kieserit \\
\hline 504 & 0.518 & $1 \mathrm{~kg}$ & $4 \mathrm{~kg} Z \mathrm{AA}$ \\
\hline Mn & 191 ppm & $55.66 \mathrm{~g}$ & $151=181 \mathrm{~g}$ MnSO4 \\
\hline Fe & $171 \mathrm{ppm}$ & 49.590 & $133-160 \mathrm{gF} 0504$ \\
\hline $2 n$ & $33 \mathrm{ppm}$ & $9.11 \mathrm{~g}$ & $22-27$ g 27504 \\
\hline Cu & $15 \mathrm{ppm}$ & $4-5 g$ & $10-13 \mathrm{gCuSOH}$ \\
\hline
\end{tabular}

Daun-daunan seperti daun trembesi (Samanea saman), daun paitan (Tithonia diversifolia),daun lantoro ( Leucaena leucocephala) sebagai bahan baku utama diperoleh dari lingkungan yang ada di sekitar kita yang sangat mudah di dapat serta dapat dimanfaatkan sebagai sarana utama untuk pembuatan ekstrak pupuk hijau organic.dari semua bahan tersebut di hancurkan untuk proses pengekstrakan dengan menggunakan alat blander untuk sekala kecil dan mesin cruser untuk sekala besar, selanjutnya ditampung dalam tangki pengekstrakan/tangki fermentasi ( ekstrac tank ). Kualitas air yang diharapkan tidak terlalu banyak karna dapat mempengaruhi hasil dari zat hijau atau klorofil serta bakteri yang di butuhkan dalam proses pengekstrakan yang terkandung dalam bahan daun-daunan tersebut Khususnya peningkatan kandungan N,P,K. N (Nitrogen), $\mathrm{P}$ (Phospor), K (Kalium) serta beberapa penyumbang total koloni bakteri.

Untuk dapat dihasilkan proses pengekstrakan serta fermentasi yang bermutu, bahan baku yang akan diolah menjadi pupuk hijau organik harus benar-benar di teliti dengan cermat, bahan apa saja yang akan digunakan serta jenis daun-daunan apa yang proses penghumusan serta mempunyai tingkat kesuburan paling tinggi pada tanah, serta harus memenuhi persyaratan penelitian pupuk hijau organic sesuai spesifikasi mutu yang telah ditetapkan , baik SPO ( standat pupuk organik), standart departemen kesehatan, atau standart lainnya. Selain itu jenis dedaunan yang sudah dilakukan proses pengekstrakan harus terlebih dahulu di teliti tentang kandungan serta unsur hara yang ada di ekstrak daun tersebut.

b) Dari jenis Limbah

- Kotoran Hewan (ternak sapi).

Kotoran sapi dapat diolah menjadi pupuk organic yang berguna untuk tanaman, Dapat meningkatkan ketrampilan masyarakat dalam membuat pupuk hijau organik yang berkualitas dari kotoran sapi dengan campuran dari ekstrak daun daunan, Dihasilkannya pupuk hiajau yang 
bermutu dengan ciri : warna coklat kehijauan, struktur gembur, berbutir halus, tidak berbau dan kandungan unsur hara yakni: C-organik, N-total, P-tersedi, K-tersedia, $\mathrm{C} / \mathrm{N}$ yang kandungannya masing-masing disajikan pada Tebl 1. Kondisi pupuk hijau organik yang dihasilkan sudah sesuai dengan kriteria pupuk organik yang bermutu menurut Isroi (2008) yakni pupuk organik yang memiliki ciri-ciri : Berwarna coklat kehijauan, tidak larut dalam air, meski sebagian pupuk dapat membentuk suspensi, nisbah C/N sebesar 10 - 20, tergantung dari bahan baku dan derajat humifikasinya, berefek baik jika diaplikasikan pada tanah, suhunya kurang lebih sama dengan suhu lingkungan, dan tidak berbau.

Tabel 2. Kandungan Unsur Hara Kotoran Sapi

\begin{tabular}{|c|c|c|}
\hline $\begin{array}{c}\text { Nama } \\
\text { Unsur }\end{array}$ & Kandungan & Keterangan \\
\cline { 2 - 2 } $\begin{array}{c}\text { C- } \\
\text { organik } \\
\text { (\%) }\end{array}$ & Kotoran sapi & \multirow{2}{*}{$\begin{array}{c}\text { Warna } \\
\text { coklat hitam, } \\
\text { struktur } \\
\text { gembur, } \\
\text { tekstur halus } \\
\text { dan berbutir } \\
\text { halus } \\
\text { (\%) }\end{array}$} \\
\hline $\begin{array}{c}\text { P-total } \\
\text { tersedia } \\
\text { (ppm) }\end{array}$ & 0,41 & \\
\hline $\begin{array}{c}\text { K- } \\
\text { tersedia } \\
\text { (ppm) }\end{array}$ & 842,31 & \\
\hline $\begin{array}{c}\text { C/N } \\
\text { ratio }\end{array}$ & $\mathbf{7 , 4 1}$ & \\
\hline
\end{tabular}

- Urine, kencing sapi atau kencing kambing.

Penggunaan feses sapi dan kambing untuk pupuk telah digunakan sejak lama, namun untuk urine belum banyak dimanfaatkan. Populasi ternak sapi di Dusun kesiman berjumlah 100 ekor yang mampu menghasilkan kurang lebih 1500 hingga 2000 liter urine setiap harinya. Jumlah yang demikian besar merupakan potensi tersendiri apabila dimanfaatkan sebagai bahan baku pembuatan pupuk organik cair sebagai sarana penunjang pemerosesan pupuk hijau organik. Dimana limbah tersebut apabila tidak ditangani dengan baik dan hanya dibuang akan sangat mengganggu dan mempengaruhi lingkungan di sekitarnya.

Dengan bantuan penelitian ini, petani ternak Dusun kesiman dibantu untuk membuat pupuk organik cair thilurine dengan bahan dasar urine yang sebelumnya tidak dimanfaatkan. Pemanfaatan ini meningkatkan nilai limbah yang tadinya tidak berharga bahkan menimbulkan masalah lingkungan menjadi suatu barang yang berharga. Hasil wawancara pendahuluan dengan petani ternak yang melakukan pembuatan pupuk organik cair thilurine tersebut memberikan informasi awal bahwa urine sapi yang digunakan sebagai bahan dasar pembuatan pupuk hijau organik dilakukan dengan pemberian bahan campuran tertentu untuk meningkatkan kandungan unsur hara seperti N, P, K dan total koloni bakteri.

c) Dari jenis material

- Zeolit

Nama zeolit berasal dari kata "zein" yang berarti mendidih dan "lithos" yang artinya batuan, disebut demikian karena mineral ini mempunyai sifat mendidih atau mengembang apabila dipanaskan. Zeolit merupakan batuan atau mineral alam yang secara kimiawi termasuk golongan mineral silika dan dinyatakan sebagai alumina silikat terhidrasi, berbentuk halus, dan merupakan hasil produk sekunder yang stabil pada kondisi permukaan karena berasal dari proses sedimentasi, pelapukan maupun aktivitas hidrotermal. Mineral zeolit dikenal sebagai bahan alam dan umumnya dalam bentuk batuan clinoptilolite, 
mordenite, barrerite, chabazite, stilbite, analcime dan laumonlite, sedangkan offerite, paulingite, dan mazzite hanya sedikit dan jarang dijumpai. Zeolit merupakan senyawa alumina silika (Si/Al) yang mempunyai pori dan luas permukaan yang relatif besar, sehingga mempunyai sifat adsorpsi yang tinggi. Zeolit dengan kandungan Si yang tinggi seperti clinoptilolite, mordenite, dan ferrierite dikelompokkan sebagai batuan acidic (Tsitsishvili et al dalam Setyowati, 2002).

Zeolit merupakan katalisator yang baik karena mempunyai poripori yang besar dengan permukaan yang luas dan juga memiliki sisi aktif. Zeolit dapat memisahkan molekul gas atau zat dari suatu campuran tertentu karena mempunyai rongga yang cukup besar dengan garis tengah yang bermacammacam (antara 2-3 $\AA$ ). Volume dan ukuran garis tengah ruang kosong dalam kristal-kristal ini menjadi dasar kemampuan zeolit untuk bertindak sebagai penyaring molekul. Molekul yang berukuran lebih kecil dapat masuk ke dalam pori, sedangkan molekul yang berukuran lebih besar dari pori akan tertahan. Untuk mendapatkan kandungan aluminium yang optimum pada zeolit dapat dilakukan dengan metode dealuminasi. Dealuminasi dapat digunakan untuk mengontrol aktivitas keasaman dan ukuran pori-pori zeolit yang berhubungan dengan fungsi zeolit sebagai penyerap (Khairinal dan Trisunaryanti, 2000). Zeolit juga meningkatkan jumlah basa-basa $\mathrm{K}, \mathrm{Na}$, Ca dan Mg serta meningkatkan KTK tanah. Namun zeolit tidak meningkatkan $\mathrm{pH}$ tanah, sementara ini ada anggapan bahwa zeolit akan menaikkan $\mathrm{pH}$ tanah. Dari hasil serapan unsur hara menunjukkan bahwa zeolit meningkatkan serapan unsur hara sejalan dengan produksi tanaman (jumlah daun, tinggi tanaman,bobot basah dan bobot kering tanaman). Dari hasil tersebut di atas dapat dibuktikan bahwa zeolit dapat mengefisiensikan penggunaan unsur hara di dalam tanah, dan ini memberi peluang yang besar untuk diterapkan pada tanaman lain dengan kondisi yang disesuaikan dengan kebutuhan tanaman yang akan dipakai. Pupuk organik dan zeolit yang diberikan secara bersamaan dengan dosis yang tepat dapat mempertahankan kelembaban tanah yang lebih lama, sehingga fluktuasi suhu di sekitar perakaran sangat kecil dan suhu tidak naik drastis (suhu tanah relatif stabil) setelah air diberikan ke tanah. Tanpa pemberian zeolit maka suhu tanah di sekitar perakaran meningkat drastis yang mengakibatkan kandungan Corganik cepat teoksidasi dan ketersediaannya di dalam tanah tidak dapat dipertahankan lebih lama lagi.

- Kapur

Bahasan tentang kapur tohor Ca $(\mathrm{OH}) 2$ meliputi kapur tohor $\mathrm{Ca}(\mathrm{OH}) 2$ dan kemungkinan larutan kapur tohor $\mathrm{Ca}(\mathrm{OH}) 2$ Kapur tohor $\mathrm{Ca}(\mathrm{OH}) 2$ atau kalsium hidroksida merupakan zat padat yang berwarna putih dan amorf . Kapur tohor (quick lime) dihasilkan dari batu gamping yang dikalsinasikan, yaitu dipanaskan pada suhu $6000 \mathrm{C}-9000 \mathrm{C}$. Kapur tohor ini apabila disiram dengan air secukupnya akan menghasilkan kapur padam (hydrated / slaked quicklime) dengan mengeluarkan panas (Sukandarrumidi, 1999 : 44). Kapur tohor merupakan anhidrida basa, dan apabila bereaksi dengan air akan terjadi kapur padam atau kalsium hidroksida. Larutan kapur tohor mengeluarkan banyak panas, bersifat basa agak keras, dan mudah menarik gas asam arang dari udara, sehingga air mudah menjadi keruh. Larutan kapur tohor juga merupakan pengikat asam - asam nabati (Setyowati , 2000 : 24). Tanah sering bersifat asam sedangkan banyak 
tumbuhan yang tumbuh baik pada suasana basa. Umumnya petani menetralisir asam dengan menggunakan kapur.

d) dari Jenis cairan

- Bakteri

Bakteri adalah kelompok dari mikroba, yang mana nikroba ini dapat menguntungkan manusia juga dapat merugikan manusia bahkan juga dapat membunuh manusia. Menguntungkan yaitu bakteri dapat sebagai pengurai atau perombak senyawa yang ada pada tanah. Sehingga kehadirannya dapat dimanfaatkan sebagai bahan campuran pengolahan pupuk hijau organic. Diantaranya bakteri yang terdapat dalam kandungan pupuk hijau organik yaitu:

bakteri EM4 adalah bakteri yang dibuat melalui proses fermentasi menggunakan bakteri (microorganisme). Kelompok mikroba yang sering digunakan adalah mikroba yang menambat $\mathrm{N}$ dari udara, mikroba yang malarutkan hara (terutama $\mathrm{P}$ dan $\mathrm{K}$ ), mikroba-mikroba yang merangsang pertumbuhan tanaman. Kelompok mikroba penambat $\mathrm{N}$ sudah dikenal dan digunakan sejak lama. Mikroba penambat $\mathrm{N}$ ada yang bersimbiosis dengan tanaman dan ada juga yang bebas (tidak bersimbiosis). Contoh mikroba yang bersimbiosis dengan tanaman antara lain adalah Rhizobium sp Sedangkan contoh mikroba penambat $\mathrm{N}$ yang tidak bersimbiosis adalah Azosprillium sp dan Azotobacter sp. Mikroba pelarut P dilaporkan oleh orang Rusia bernama Pikovskaya pada tahun 1948 yaitu

Bacillus megatherium var. phosphaticu $\mathrm{m}$, dan mulai digunakan sebagai inokulum pertanian sejak tahun 1950an, beberapa mikroba yang diketahui dapat melarutkan $\mathrm{P}$ dari sumber-sumber yang sukar larut ditemukan baik dari kelompok kapang/fungi seperti
Penicillium sp dan Aspergillus sp, atau dari kelompok bakteri seperti Bacillus sp dan Pseudomonas sp. Mikroba pelarut fosfat dimanfaatkan untuk memperkaya fosfat alam. Fosfat alam granul di dalam foto di atas sudah diperkaya dengan mikroba pelarut fosfat. Mikroba lain yang juga sering digunakan adalah Mikoriza, yang terdiri dari dua kelompok utama yaitu: endomikoriza dan ektomikoriza. Mikoriza bersimbiosis dengan tanaman. Secara mudahnya endomikoriza berarti mikoriza yang ada di dalam dan ektomikoriza adalah mikoriza yang ada di luar. Endomikoriza atau VAM umumnya adalah fungi tingkat rendah sedangkan ektomikoriza adalah jamur tingkat tinggi. Mikroriza memiliki peranan yang cukup komplek. Dia tidak hanya berperan membantu penyerapan hara $\mathrm{P}$, tetapi juga melindungi tanaman dari serangan penyakit dan memberikan nutrisi lain bagi tanaman. Mikroba yang juga sering digunakan sebagai biofertilizer adalah mikroba perangsang pertumbuhan tanaman. Mikroba dari kelompok bakteri sering disebut dengan Plant Growt Promoting Rhizobacteria (PGPR), namun sekarang juga diketahui bahwa ada juga fungi yang dapat merangsang pertumbuhan tanaman. Bakteri yang diketahui dapat merangsang pertumbuhan tanaman antara lain adalah Pseudomonas sp, Azosprillium sp, Sedangkan fungi yang sudah diketahui adalah Trichoderma sp. Pseudomonas sp, salah satu bakteri PGPR yang menghasilkan hormon.

Mikroba mikroba bahan aktif pupuk organik dikemas dalam bahan pembawa, bisa dalam bentuk cair atau padat. Pupuk organik juga ada yang hanya terdiri dari satu atau beberapa mikroba saja, tetapi ada juga yang mengklaim terdiri dari bermacam macam mikroba. Pupuk organik ini yang kemudian diaplikasikan ke 
tanaman. Saat ini dipasaran banyak beredar pupuk organik. Sebagian mengklaim memiliki kandungan mikroba yang banyak dan lengkap dengan kemampuan luar biasa. Secara pribadi saya tidak percaya dengan biofertilizer yang memiliki banyak mikroba dan efektif di semua tempat, semua komoditas, dan semua kondisi. Salah satu kelembahan mikroba adalah sangat tergantung dengan banyak hal. Mikroba sangat dipengaruhi oleh kondisi lingkungannya, baik lingkungan biotik maupun abiotik. Jadi biofertilizer yang cocok di daerah sub tropis belum tentu efektif di daerah tropis. Demikian juga biofertilizer yang efektif di Indonesia bagian barat, belum tentu efektif juga di wilayah Indonesia bagian timur. Mikroba yang bersimbiosis dengan tanaman lebih spesifik lagi. Misalnya Rhizobium sp yang bersimbiosis dengan kedelai varietas tertentu belum tentu cocok untuk tanaman kacang-kacangan yang lain. Umumnya mikroba yang bersimbiosis berspektrum sempit.

- Molase/Tetes tebu

Tetes tebu merupakan hasil samping industri gula yang mengandung senyawa nitrogen, trace element, dan kandungan gula yang cukup tinggi terutama kandungan sukrosa sekitar $34 \%$ dan kandungan karbon sekitar $37 \%$, yang dapat mengembalikan kondisi tanah yang keritis dengan bantuan bakteri. (Suastuti, 1998).

- Asam cuka

Asam adalah senyawa kimia yang bereaksi dengan basa,membentuk kation atau menerima elektron. Basa adalah senyawa kimia yang bereaksi dengan asam, membentuk anion atau elektron. Larutan asam basa juga dikenal di kalangan pertanian dan lingkungan hidup yaitu berkhaitan dengan $\mathrm{PH}$ atau derajat keasaman tanah dan air. PH merupakan ukuran kekuatan asam. Pengujian $\mathrm{PH}$ dapat ditentukan dengan indicator universal. Kata asam berasal dari bahasa latin ," acidum “ atau "acid" bahasa inggris. Kata asam di khaitkan dengan rasa asam dengan senyawa-senyawanya. Lawan asam yaitu “ alkali” , kata ini berasal dari bahsa arab yang berarti " abu tanamtanaman “. Senyawa alkali lebih di kenal dengan nama basa.

\section{METODOLOGI PENELITIAN}

\section{Pengumpulan Data}

a. Observasi Yaitu suatu cara pengumpulan data untuk memperoleh data dan informasi dengan melakukan pengamatan secara langsung dan mencatat data yang diperlukan dari aktivitas obyek yang diteliti.

b. Studi Kepustakaan

Yaitu suatu tinjauan kepustakaan dimana semua bahan yang berhubungan dengan landasan teori yang diperoleh dari literatur, catatan kuliah serta pengkajian buku-buku di balai pustaka LIPPI (kebunraya purwodadi pasuruan) dengan harapan dapat mendukung pembahasan masalah berpedoman pada teori dan pikiran yang logis.

\section{Pengolahan Data}

a.Eksperimen proses produksi pupuk organik adalah mencoba merumuskan proses pembuatan pupuk organik

b. Study karakter, fenologi, habitat, etnobotani dan kearifan Tradisional.Untuk mengetahui karakter dari tumbuhan serta daun daunan yang di buat penelitian melalui cara tradisional.

c. Study uji banding dengan pupuk organik yang lain.

Study ini dilakukan untuk mengetahui perbandingan tingkat kesuburan pupuk 
hijau organic dengan pupuk organic lain

\section{HASIL DAN PEMBAHASAN}

Komposisi hara dalam pupuk organik sangat tergantung dari sumbernya, menurut sumbernya, pupuk organik dapat diidentifikasi berasal dari pertanian dan non pertanian, dari pertanian dapat berupa sisa panen dan kotoran ternak, sedangkan dari non pertanian dapat berasal dari sampah organik kota, limbah industri dan sebagainya, bahan organik dari berbagai sumber ini sering dikomposkan terlebih dahulu untuk meningkatkan mutu gizinya

Table 3. Persaratan teknis minimal pupuk organik

\begin{tabular}{|c|c|c|c|}
\hline $\begin{array}{l}\mathrm{N} \\
\mathrm{O}\end{array}$ & Perameter & $\begin{array}{c}\text { Kandungan } \\
\text { padat }\end{array}$ & $\begin{array}{c}\text { Kandungan } \\
\text { cair }\end{array}$ \\
\hline 1 & $\begin{array}{c}\mathrm{C} \text { - organic } \\
(\%)\end{array}$ & $\geq 12$ & $\geq 45$ \\
\hline 2 & $\mathrm{C} / \mathrm{N}$ rasio & $10-25$ & - \\
\hline 3 & $\begin{array}{l}\text { Bahan ikutan } \\
\text { (\%), (krikil, } \\
\text { beling,plastic } \\
\text { ) }\end{array}$ & $\geq 2$ & - \\
\hline \multirow[t]{3}{*}{4} & \multirow{3}{*}{$\begin{array}{c}\text { Kadar air (\%) } \\
\text { _ Granula } \\
\text { _ Curah }\end{array}$} & & \\
\hline & & 4-12 & - \\
\hline & & $13-20$ & - \\
\hline \multirow[t]{5}{*}{5} & \multirow{5}{*}{$\begin{array}{c}\text { Kadar logam } \\
\text { berat } \\
\text { As (PPM) } \\
\text { Hg (PPM) } \\
\text { Pb (PPM) } \\
\text { Cd (PPM) }\end{array}$} & & \\
\hline & & $\leq 10$ & $\leq 10$ \\
\hline & & $\leq 1$ & $\leq 1$ \\
\hline & & $\leq 50$ & $\leq 50$ \\
\hline & & $\leq 10$ & $\leq 10$ \\
\hline 6 & $\mathrm{PH}$ & $4-8$ & $4-8$ \\
\hline \multirow[t]{3}{*}{7} & \multirow{3}{*}{$\begin{array}{l}\text { Kadar total } \\
\text { _ P2O5 (\%) } \\
\text { _ K2O (\%) }\end{array}$} & & \\
\hline & & $\leq 5$ & $\leq 5$ \\
\hline & & $\leq 5$ & $\leq 5$ \\
\hline 8 & $\begin{array}{c}\text { Mikroba } \\
\text { pathogen(e- } \\
\text { coli } \\
\text { salmonella) }\end{array}$ & $\begin{array}{c}\text { Dicantumka } \\
n\end{array}$ & $\begin{array}{c}\text { Dicantumka } \\
n\end{array}$ \\
\hline \multirow[t]{6}{*}{9} & $\begin{array}{c}\text { Kadar unsure } \\
\text { mikro (\%) }\end{array}$ & & \\
\hline & $\mathrm{Zn}, \mathrm{Cu}, \mathrm{Mn}$ & Max 0.500 & Max 0.2500 \\
\hline & Co & Max 0.002 & 0.0005 \\
\hline & $\mathrm{B}$ & 0.250 & 0.1250 \\
\hline & MO & & 0.0010 \\
\hline & $\mathrm{Fe}$ & 0.400 & 0.04000 \\
\hline
\end{tabular}

Untuk mengetahui kesesuaian pupuk organic dengan persyaratan teknis minimal perlu dilakukan pengujian mutu pupuk organic di lab yang terakreditasi atau yang ditunjuk oleh menteri pertanian, melalui SK MENTAN, seperti pembuatan dengan pupuk organik, maka syarat pendaftaran pupuk organic telah dituangkan dalam SK Mentan no:2 tahun 2006.

Tabel 4. Persyaratan teknis minimal pembenah tanah

\begin{tabular}{|c|l|c|}
\hline No & Parameter & Kandungan \\
\hline 1 & $\begin{array}{l}\text { Bahan aktif } \\
(\%)\end{array}$ & Dicantumkan \\
& /Sintetis & \\
\hline 2 & $\begin{array}{l}\text { KTK ** ( } \\
\text { cmol ( + } \\
\text { )kg-1 }\end{array}$ & $\geq 80$ \\
\hline 3 & PH & $4-8$ \\
\hline 4 & Kadar & $<10$ \\
& $\begin{array}{l}\text { logam } \\
\text { berat(ppm) }\end{array}$ & $<1$ \\
& AS ( ppm) & $<50$ \\
& Hg (ppm) & $<10$ \\
& PB (ppm) & \\
& Cd (ppm) & \\
\hline
\end{tabular}

Pembersih tanah di definisikan sebagai bahan -bahan sintetis atau alami organic atau mineral, bentuk padat maupun cair yang mampu meperbaiki sifat fisik, kimia, dan biologi tanah. Pembenah tanah sintetis adalah : bahan pembenah tanah yang diproduksi secara rekayasa kimia, dari bahan -bahan organic atau mineral, yang dapat digunakan untuk memperbaiki sifat-sifat tanah, sedangkan bahan alami yaitu bahan bahan organic tanpa proses kimia yang dapat memperbaiki sifat - sifat tanah melalui proses penghumusan tanpa bahan kimia. 
Tabel 5. Data unsur daun - daunan pupuk hijau organik

\begin{tabular}{|c|c|c|c|c|c|}
\hline \multirow{2}{*}{ No } & Jenis daun & $\mathrm{Kg}$ & $\begin{array}{c}\text { Unsur } \\
(\mathrm{N})\end{array}$ & $\begin{array}{c}\text { Unsur } \\
(\mathrm{P})\end{array}$ & $\begin{array}{c}\text { Unsur } \\
(\mathrm{K})\end{array}$ \\
\cline { 1 - 4 } 1 & $\begin{array}{c}\text { Daun } \\
\text { trembesi }\end{array}$ & 5 & 6.52 & 0.47 & 2,25 \\
\hline 2 & daun paitan & 3 & 4,65 & 0,25 & 64,52 \\
\hline 3 & $\begin{array}{c}\text { daun } \\
\text { lantoro }\end{array}$ & 3 & 3,37 & 0.31 & 0,37 \\
\hline
\end{tabular}

Tabel 6. Data limbah ternak sapi

\begin{tabular}{|c|c|c|c|c|}
\hline $\begin{array}{c}\text { jeni } \\
\mathrm{s}\end{array}$ & $\begin{array}{c}\mathrm{Kg} / \mathrm{lt} \\
\mathrm{r}\end{array}$ & $\mathrm{N}$ & $\mathrm{P}$ & $\mathrm{K}$ \\
\hline $\begin{array}{c}\text { Pad } \\
\text { at }\end{array}$ & $\begin{array}{c}10 \\
\mathrm{~kg}\end{array}$ & $\begin{array}{c}0,6 \\
5\end{array}$ & $\begin{array}{c}0,1 \\
5\end{array}$ & $\begin{array}{c}0,3 \\
0\end{array}$ \\
\hline Cair & $1 \mathrm{ltr}$ & $\begin{array}{c}0,5 \\
3\end{array}$ & $\begin{array}{c}0,3 \\
5\end{array}$ & $\begin{array}{c}0,4 \\
1\end{array}$ \\
\hline
\end{tabular}

Diagram Alir Proses Pupuk Hijau Organik

\section{Pemerosesan Ekstrak dari Daun - Daunan.}

Ekstrak daun - daunan lebih mudah terserap oleh tanaman karena unsur-unsur di dalamnya sudah terurai. Tanaman menyerap unsur hara terutama melalui akar. Sehingga ada manfaatnya apabila daun - daunan tersebut di fermentasi serta di proses sebagai bahan utama campuran pembuatan pupuk hijau organik dan diberikan di sekitar tanaman.

\section{Bahan - Bahan}

Pupuk organik bisa dibuat dari bahan yang mempunyai unsur-unsur yang mudah atau bisa terurai di dalam tanah, misalnya:

- Daun trembesi (Samanea saman)

- Daun paitan (Tithonia diversifolia)

- Daun lantoro ( Leucaena Leucocephala)

Alat - alat yang diperlukan:

Mesin blander, pengaduk mesin blander, drum plastik/baskom hasil ekstrak, saringan kelapa.

Cara pembuatan :
Masukkan daun trembesi kedalam mesin blander tuangkan air seper empat mili liter / secukupnya, jangan terlalu banyak dan juga jangan terlalu sedikit karna fungsi dari air sendiri dalam proses ini agar mesin tidak macet. Jika air terlalu banyak maka dapat mempengaruhi kandungan jat hijau yang ada di fermentasi tersebut. Tutup mesin blander agar bahan baku tidak tumpah, hidupkan mesin dalam putaran penuh. Aduklah bahan baku agar proses lebih sempurna. Setelah proses pengekstrakan daun trembesi selesai saring dengan saringan kelapa atau alat penyaringan lain lalu tuang ekstrak daun trembesi tersebut kedalam drum plastik tutup rapat biarkan ekstrak tersebut dalam tiga hari agar hasil ekstrak agak mengental dan berbusa.

Setelah selesai proses pengekstrakan daun trembesi, masukkan daun paitan kedalam mesin blander lakukan pemerosesan seperti proses daun trembesi, hasil dari blender saring ekstrak daun paitan tersebut agar terpisah dari serpihan daun kemudian tuang ekstrak daun trembesi tersebut kedalam drum plastik/baskom lain, tutup rapat - rapat biarkan ekstrak daun paitan tersebut selama tiga hari agar hasil ekstrak tersebut berfermentasi dan menjadi peptisida secara alami.Proses pengekstrakan yang terakhir, masukkan daun lantoro kedalam mesin blender lakukan proses pengekstrakan seperti daun trembesi dan daun paitan, jika semua proses telah selesai tuang daun lantoro tersebut kedalam drum plastik/baskom tutup rapat tunggu tiga hari hingga cairan fermentasi tersebut mengental dan hasil ekstrak bener benar telah sempurna.

\section{- Pemerosesan fermentasi}

Daun dapat dimanfaatkan untuk bahan baku mengumpulkan mikroorganisme. Fungsi dari daun - 
daunan dan bahan campuran lainnya adalah memberi makanan pada mikroorganisme.

1. Bahan-bahan yang diperlukan adalah:

fermentasi bakteri, ekstrak daun trembesi, ekstrak daun paitan, ekstrak daun lantoro, urine sapi,maxtro, molase/ tetes tebu, dan asam cuka.

2. Alat - alat yang digunakan:

- Ember/ gentong/ drum plastik yang dapat di tutup rapat

3. Cara pembuatan:

- Masukkan larutan bakteri kedalam drum plastik

- Masukkan ekstrak daun - daunan kedalam drum plastik

- Masukkan urine sapi kedalam drum plastik

- Masukkan maxtro kedalam drum plastik

- Masukkan molase/tetes tebu kedalam drum plastik

- Masukkan asam cuka kedalam drum plastik

Setelah semua bahan telah dimasukkan tutup rapat drum tersebut jangan sampai terjadi kebocoran. Setelah $8-10$ hari hasil fermentasi pencampuran bahan sudah selesai dan drum sudah dapat dibuka saring dan masukkan dalam wadah yang bersih/ dirigen plastik untuk disimpan dan fermentasi tersebut sudah dapat digunakan sebagai campuran dari pupuk hijau organik. Kegunaan : Sebagai bahan utama pembuatan dari pupuk hijau organik, manfaat lain mempercepet pengomposan dari 3-4 bulan menjadi 15 - 30 hari, dapat digunakan langsung sebagai pupuk semprot. Larutan ini bisa digunakan untuk menyiram sayuran dari pembenihan hingga masa panen. Larutan ini juga merangsang pertumbuhan tanaman, melapukkan bahan organik dalam tanah, perbaikan tanah dan mendorong kehidupan mikroorganisme dalam tanah.

\section{- Proses Penghancuran (Cruser)}

Dalam proses ini bahan baku dari kotoran ternak, terutama kotoran sapi kita cruser/ giling bahan hingga membentuk seperti serbuk gunanya agar mempermudah dalam proses pengepanan, dalam proses ini bahan baku dari kotoran sapi yang masih dalam bentuk gumpalan kering dapat kita ubah menjadi serbuk bahan pembuat pupuk hijau organic, dari bentuk serbuk tersebut kita dapat dengan mudah membentuk butiran kecil dalam pemerosesan selanjutnya pada mesin pan.

1. Bahan - bahan yang di gunakan:

- Kotoran sapi ( jenis kotoran hewan ternak lain seperti:kambing, kelinci dan ayam).

- Daun trembesi $5 \mathrm{~kg}$, daun paitan $3 \mathrm{~kg}$ dan daun lantoro $3 \mathrm{~kg}$. daun daunan tersebut masih dalam keadaan hijau.

2. Alat - alat yang di gunakan:

- Mesin cruser

- Karung plastic

3. Adapun cara proses kotoran sapi pada mesin cruser yaitu:

- Hidupkan mesin cruser

- Masukkan kotoran sapi yang sudah kering kedalam mesin cruser, proses hingga benar benar menjadi serbuk, jika proses sudah selesai masukkan kedalam karung plastic, agar mudah dalam pengangkutan/ pemindahan barang.

- Masukkan daun - daunan tersebut kedalam mesin cruser, proses daun daunan tersebut sampai selesai. Jika proses cruser daun - daunan tersebut sudah selesai masukkan ke karung plastic. 
Matikan mesin cruser jika proses sudah selesai, kemudian pindahkan bahan baku tersebut kedekat mesin pan sebagai persiapan proses selanjutnya.

\section{- Proses}

\section{Pembentukan}

(Pengepanan).

Pada dasarnya Pupuk organik Padat / Kering dapat terbuat dari serasah tanaman, daun, ranting yang jatuh ke tanah dan akar-akar / bagian tanaman yang telah mati. Bahan-bahan tersebut secara cepat dan tepat akan dimetabolisme oleh mikroorganisme (jasad renik; mahluk hidup berupa satwa atau tumbuhan) yang diubah menjadi bahan humus yang stabil. Dalam proses ini bahan - bahan dari pupuk hijau organic, terutama bahan dari fermentasi daun - daunan dan kotoran sapi dibentuk hingga menjadi butiran kecil atau menjadi pupuk hijau organic padat.

1. bahan - bahan yang di gunakan:

- Hasil fermentasi daun - daunan dan bahan lain 5 liter.

- Kotoran sapi yang sudah selesai di cruser $10 \mathrm{~kg}$.

- Daun - daunan yang sudah selesai di cruser

- Zeolit

- Kapur

2. Mesin dan alat - alat yang digunaka:

- Mesin pan

- Papan pembalik bahan baku pada mesin pan

- Skop untuk mengangkat butiran pupuk yang sudah selesai diproses

- Timba untuk tempat cairan fermentasi

- Karung plastic sebagai wadah hasil proses

3. Adapun cara pemerosesannya yaitu:

- Masukkan kotoran sapi kedalam mesin pan
- Masukkan daun - daunan yang sudah selesai dicruser

- Masukkan zeolit

- Masukkan kapur

Jika semua bahan sudah selesai dimasukkan kedalam mesin pan, hidupkan mesin pada putaran normal, lalu semprot dengan air fermentasi agar bahan baku tidak bertebaran tunggu sampai $1 / 4 \quad$ jam kemudian lakukan pembalikan dengan skop agar bahan baku tidak menggumpal, sekiranya bahan baku masih agak kering semprot lagi dengan cairan fermentasi. Aduk lagi bahan baku tersebut. Dalam hal ini sebenarnya tidak ada batasan waktu untuk penyemprotan, karma dalam hal ini yang dibutuhkan yaitu keahlian, pengalaman, serta ketelitian sang operator tetapi rata - rata waktu dalam pemerosesan adalah 1 jam $1 / 2$ mulai awal proses sampai bahan baku selesai dip roses.

\section{- Proses Pemanasan ( Drayer).}

Dalam proses ini bahan baku yang masih basah diproses/ dipanas kan menggunakan mesin drayer, proses ini bertujuan agar bahan baku yang masih basah dapat berubah menjadi kering dan mengeras.

1. bahan baku yang di gunakan

- Butiran pupuk hijau organic yang masih dalam keadaan basah.

2. mesin dan alat- alat yang digunakan:

- Pemanas mesin drayer ( boiler) Mesin drayer

3. cara pemerosesannya yaitu:

- Hidupkan pemanas mesin drayer

- Hidupkan mesin drayer agar berputar

- Masukkan Butiran pupuk hijau organic yang masih dalam keadaan basah kedalam corong mesin drayer.

Dalam prosen ini memakan waktu satu jam untuk mengubah butiran yang masih basah menjadi butiran kering. 
Setelah proses pada mesin drayer selesai angkut dengan wadah untuk dilakukan proses penyaringan pada mesin pemilah.

\section{- Proses Penyaringan (Pemilahan)}

Dalam proses pemilahan ini bertujuan agar bentuk dari butiran ini sama dalam hal ukuran diameternya, sedangkan untuk butiran yang lebih besar kita dapat mendaur ulang pupuk yang sudah mengeras tersebut dengan menggunakan mesin cruser dan kita proses mulai dari awal pemerosesan.

1. Alat - alat yang digunakan:

- Saringan pasir dengan ukuran diameter perlubang 5 mili meter.

2. cara pemerosesannya yaitu:

bahan baku yang telah jadi tersebut masukkan kedalam saringan/ mesin pemilah lakukan pengoyakan baik secara manual atau menggunakan mesin penggerak, siapkan wadah atau alat penampung bahan yang sudah selesai di pilah.

\section{- Proses Pendinginan}

Proses pendinginan sendiri bertujuan agar bahan baku yang masih dalam keadaan panas cepat menjadi dingin, karna dalam hal ini bahan baku sama seperti tanah yang sedang di bakar. Jika proses pendingina sudah selesai kita bisa mengemasnya dan siap kita kirim ke konsumen atau kita gunakan untuk pupuk para petani yang ada disekitar kita, sehingga kita dapat mengetahui kemampuan serta manfaat kesuburan bagi tanah serta tanaman yang selama ini telah teracuni oleh pupuk yang berbahan baku dari zat kimia.

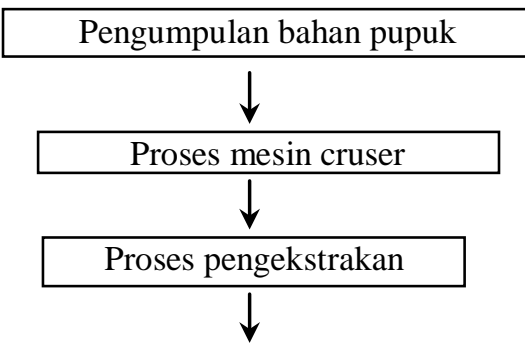

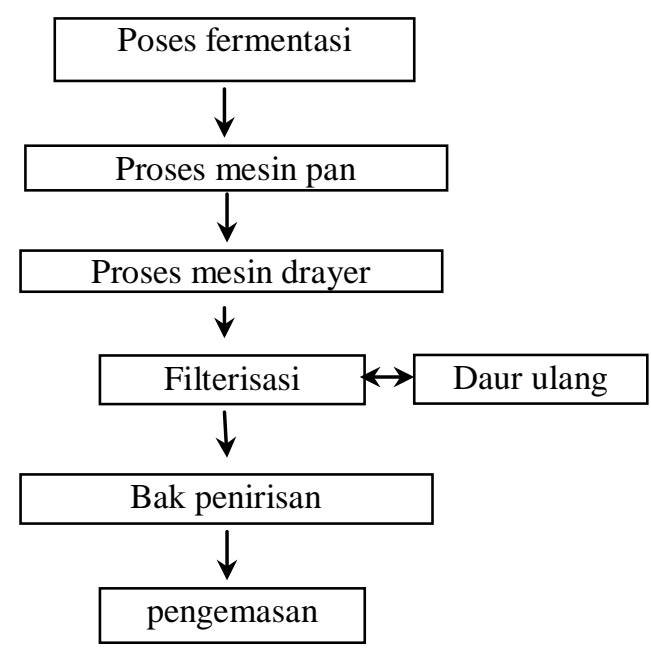

\section{KESIMPULAN}

Berdasarkan hasil penelitian yang dilakukan. Mengenai proses produksi pupuk hijau organik yang berbahan baku utama dari daun daunan serta bahan campuran organik lainnya, penulis mengambil suatu kesimpulan, setelah mengadakan pembahasan di bab sebelumnya dan juga mengajukan saran yang mungkin dapat berguna bagi pihak universitas, baik itu jurusan teknik industri, pertanian maupun dari kalangan para petani terutama bagi industri pupuk organik yang ada di indonesia khususnya wilayah jawa timur.

Beberapa kesimpulan yang dapat di ambil dari uraian sebelumnya adalah sebagai berikut.

1. Berdasarkan Studi Uji lab kandungan unsur hara N,P,K banyak terdapat pada daun - daunan terutama Daun trembesi (Samanea saman) dengan kandungan unsure $(\mathrm{N})=6.52$, unsure $(\mathrm{P})=0.47$ dan unsure $(\mathrm{K})=2,25$. Untuk daun paitan (Tithonia diversifolia) kandungan unsure $(\mathrm{N})=$ 4,65, unsure $(\mathrm{P})=0,25$ dan unsure $(K)=64,52$. Sedangkan untuk daun lantoro (Leucaena leucocephala) kandungan unsure $(\mathrm{N})=3,37$, unsure $(\mathrm{P})=0.31$ dan unsure $(\mathrm{K})=0,37$. 
Dari data uji lab tersebut dalam setiap unsur hara serta kandungan zat hijau yang terdapat pada daun trembesi menunjukkan bahwa nilai kandungan unsur $(\mathrm{N})$ pada daun trembesi berada diatas nilai yang distandarkan, sedangkan untuk unsure (K) yang berada diatas nilai standar terdapat pada daun paitan dan unsure $(\mathrm{P})$ yang berada diatas nilai standart terdapat pada daun lantoro. Dengan demikian kandungan unsure ketiga bahan tersebut dapat kita gabungkan untuk dijadikan sebagai alat ukur pada variabel proses produksi pupuk hijau organic yang akan diuji.

Dari hasil Studi karakter, fenologi, habitat, etnobotani dan kearifan tradisional, menyatakan bahwa ada pengaruh terhadap kondisi tanah yang kritis yang semula tidak begitu subur dengan tingkat pencemaran zat kimia tinggi, telah berangsur pulih akibat penghumusan yang di akibatkan dari pupuk hijau organik yang telah kami teliti.

2. Studi uji banding dengan pupuk organik yang lain. Merupakan hasil proses pengambilan sampel apakah perbedaan tingkat kesuburan yang diperoleh dapat signifikan untuk menjelaskan keragaman pupuk organik.

3. Hasil proses produksi pupuk hijau organik menunjukkan bahwa pupuk hijau organik dengan bahan baku dari daun trembesi,paitan dan lantoro serta jenis bahan campuran lain yang tidak memiliki kandungan bahan kimia yang dapat merusak kesuburan tanah secara alami, patut dan layak untuk di gunakan sebagai pupuk organik yang memiliki standart kelayakan pupuk organik, karna tingkat kesuburan pada tanah lebih cepat dari pada jenis pupuk organik padat yang lain.

\section{SARAN}

Adapun saran yang dapat diberikan dari hasil penelitian ini ialah: dari hasil penelitian menunjukkan bahwa proses produksi pupuk hijau organik tidak bisa menghasilkan produk secara maksimal ketika hanya menggunakan peralatan yang sederhana/ manual saja. Dan proses produksi akan menghasilkan produk yang maksimal sesuai yang kita harapkan ketika semua mesin serta peralatan dan juga modal berjalan seimbang. Dari sini, kerja keras harus selalu ditekankan khususnya dalam hal proses produksi,

\section{DAFTAR PUSTAKA}

Hari dan Daryanto. 1999.Ilmu Bahan. Jakarta : Bumi Aksara

Iftikar, Z Sutalaksana, DKK.1979 “Teknik Tata Cara Kerja” Bandung : Departemen Teknik Industri ITB.

Ginting Rosnani 2009, Sistem Produksi Penerbit Graha Ilmu Jakarta

Kusuma, Hendra 2009, Manajemen

Produksi Penerbit Andi Yogyakarta

Nasution, Arman.H 2005, Manajemen Industri.Penerbit Andi Yogyakarta

Wignjosoebroto, Sritomo.1989. Teknik

Tata Cara Dan Pengukuran Kerja. ITS Surabaya

Nasution, Arman.H 2009, Teknik

Perancangan Dan

Pengembangan Produk,

Penerbit Andi Yogyakarta

Miranty, 2005.Rencana usaha yang Rasional,Yayasan bina karsa mandiri,Jakarta 
WRI, IUCN dan UNEP. 1995. Strategi

Keanekaragaman Hayati

Global. Terjemahan. Gramedia.

Jakarta.

Primack, R.B., dkk. 1998. Biologi

Konservasi. Yayasan Obor

Indonesia. Jakarta

Maspary, Suria Wiria 1986, Fungsi

Unsur Hara Dalam Proses

Pertumbuhan dan

Perkembangan

Tanaman,Gramedia Jakarta

Myung dan Lee, 2001, kandungan beberapa unsur kimia pada limbah industri cair, Terjemahan Gramedia Jakarta

Duke and Wain, 1981, Kandungan Unsur Hara Daun Trembesi, Venezuela University

Suriadikarta dan Setyorini, Kandungan Unsur Hara Daun Lantoro, Andi Yogyakarta

SK MENTAN No 02 Tahun 2006 "Persyaratan Teknis Minimal Pupuk Organik"

Lab Pertanian Univ.Brawijaya 2012,Komposisi Hara Dalam Tanah

Lab Pertanian Univ.Brawijaya2012,,Komposisi Hara Limbah Ternak Sapi

Lab Pertanian Univ.Brawijaya2012,,Kandunga n Unsur Daun-daunan Pupuk Hijau Oganik 